\title{
Longitudinal Survey of Lymphocyte Subpopulations in the First Year of Life
}

\author{
ESTHER DE VRIES, SANDRA DE BRUIN-VERSTEEG, W. MARIEKE COMANS-BITTER, \\ RONALD DE GROOT, WIM C. J. HOP, GEERT J. M. BOERMA, FRED K. LOTGERING, AND \\ JACQUES J. M. vAN DONGEN
}

\begin{abstract}
Departments of Immunology [E.d.V., S.d.B.-V., W.M.C.-B., J.J.M.v.D.] and Epidemiology and Biostatistics [W.C.J.H.], Erasmus University Rotterdam, Rotterdam, Department of Pediatrics [S.d.B.-V., W.M.C.-B., R.d.G.], Sophia Children's Hospital, Departments of Clinical Chemistry [G.J.M.B.] and Obstetrics and Gynecology [F.K.L.], University Hospital, Rotterdam, Rotterdam, and Department of Pediatrics [E.d.V.], Bosch Medicentrum, 's-Hertogenbosch, The Netherlands
\end{abstract}

\section{ABSTRACT}

\begin{abstract}
Age-matched reference values for lymphocyte subpopulations are generally obtained via cross-sectional studies, whereas patients are followed longitudinally. We performed a detailed longitudinal analysis of the changes in lymphocyte subpopulations in a group of 11 healthy infants followed from birth up to $1 \mathrm{y}$ of age, with special attention for early developmental markers, markers of maturation, and markers of activation. We found that $\mathrm{T}$ and $\mathrm{B}$ lymphocytes increased at 1 and $6 \mathrm{wk}$ of age, respectively. In contrast, NK cells showed a sharp decline directly after birth, suggesting that they are more important during pregnancy than thereafter. CD $45 \mathrm{RA}^{+}$- mainly $\mathrm{CD} 4^{+}$—naive $\mathrm{T}$ lymphocytes were high at birth, and increased further during the first year of life; they form a large expanding pool of cells, ready for participation in primary immune responses. The absolute counts of $\mathrm{CD} 45 \mathrm{RO}^{+}$memory $\mathrm{T}$ lymphocytes were similar in infants and adults, albeit with a lower level of expression of CD45RO on infant T lymphocytes. Almost all infant T lymphocytes expressed CD38 throughout the first year of life. The abundant expression of CD38 on an infant's T lymphocytes might be related to a greater metabolic need of the large popu-
\end{abstract}

lation of naive untriggered cells that are continually involved in primary immune responses during the first year of life. The high B lymphocyte counts in infants mainly concerned $\mathrm{CD} 38^{+} \mathrm{B}$ lymphocytes throughout the first year of life. Also, the relative frequencies of $\mathrm{CD}_{1} \mathrm{c}^{+}$and $\mathrm{CD}^{+} \mathrm{B}$ lymphocytes were higher throughout the first year of life than in adults. Therefore, CD1c, CD5, and CD38 could be markers of untriggered B lymphocytes. In conclusion, our longitudinal survey of $\mathrm{T}$ and $\mathrm{B}$ lymphocytes, NK cells, and their subpopulations during the first year of life helps to complete the picture of lymphocyte development in infants. This information contributes to the correct interpretation of data from infants with possible immune disorders. (Pediatr Res 47: 528-537, 2000)
Abbreviations
CD4/CD8, ratio between helper and suppressor T lymphocytes NK, natural killer
TCR, $\mathrm{T}$ cell receptor

Immunophenotyping of blood lymphocyte subpopulations is an important tool in the diagnosis and follow-up of children with immune disorders. Correct interpretation of the obtained results requires knowledge of the normal development of the immune system during the first years of life.

For this purpose, several sets of age-matched reference values of relative frequencies and absolute counts of lymphocyte subpopulations in childhood have been reported (1-5). Because of the higher blood lymphocyte counts in neonates and infants compared with adults $(1,6)$, differences in lymphocyte subpopulations are better reflected by comparison of absolute counts than relative frequencies. In that way, trends

Received May 5, 1999; accepted June 29, 1999.

Correspondence to: Dr. E. de Vries, Department of Immunology, Erasmus University Rotterdam, PO Box 1738, 3000 DR Rotterdam, The Netherlands. are observed that are missed when only relative frequencies are used (1). These absolute lymphocyte counts are more accurately determined by the lysed whole blood technique than by analysis after density gradient separation $(7,8)$.

To date, age-matched reference values for lymphocyte subpopulations were all obtained in cross-sectional studies. Longitudinal studies in individual children are more informative about the pattern of lymphocyte subpopulation development as a function of time. Children with immune disorders are also followed longitudinally. Therefore, it is useful to compare patient data with data from studies on longitudinal development of lymphocyte subpopulations in healthy children. Such longitudinal follow-up studies can also assess the influence of factors such as infection and vaccination on the size of lymphocyte subpopulations. This information is important for 
correct timing of lymphocyte subpopulation studies for diagnostic purposes as well as for disease monitoring in patients.

We therefore performed a detailed longitudinal analysis of lymphocyte subpopulations by immunophenotyping with a lysed whole blood microassay in a group of 11 healthy infants followed from birth to $1 \mathrm{y}$ of age. We studied helper and cytotoxic T lymphocytes, B lymphocytes, NK cells, and their subpopulations. Because the presence of immature as well as of activated cells has been described in neonatal samples in the past (9), special attention was paid to the expression of early developmental markers, markers of maturation, and markers of activation.

\section{METHODS}

Subjects and cell samples. Immediately after clamping of the cord, neonatal cord blood was collected by venipuncture from 11 healthy infants born after an uncomplicated pregnancy and delivery at gestational ages of $35 \mathrm{wk}$ (infant 10), $37 \mathrm{wk}$ (infant 6), $38 \mathrm{wk}$ (infant 4), $40 \mathrm{wk}$ (infants 2, 3, 9, and 11), and $41 \mathrm{wk}$ (infants 1, 5, 7, and 8). At the age of $7 \mathrm{~d}, 6 \mathrm{wk}, 3 \mathrm{mo}$, $6 \mathrm{mo}$, and $1 \mathrm{y}$, additional blood samples were collected by venipuncture from the same infants (infant 11 was lost to follow-up at 6 mo of age). The blood was kept at room temperature until immunostaining was performed within $12 \mathrm{~h}$ after sampling. Every time a blood sample was taken, a physical examination of the infant was performed by the pediatrician (E.d.V.), and questions about infections, vaccinations, feedings, and development were answered by the mother. Adult peripheral blood was drawn by venipuncture from nine healthy adult volunteers (age, 20 to $40 \mathrm{y}$ ). EDTA was used as anticoagulant. Informed consent was obtained according to the guidelines of the Medical Ethics Committee of the Erasmus University Rotterdam/University Hospital Rotterdam.

Flow cytometric analysis. The MAb used in 30 triple labelings (listed in Table 1) were conjugated with FITC, phycoerythrin, or the duochrome phycoerythrin-cyanin 5 . The same set of 30 triple immunostainings was used in all samples to enable accurate comparison of the relative and absolute sizes of the different $\mathrm{T}$ lymphocyte $\left(\mathrm{CD}^{+}\right)$, B lymphocyte $\left(\mathrm{CD} 19^{+}\right)$, and $\mathrm{NK}$ cell $\left(\mathrm{CD}^{-} / \mathrm{CD}^{-} 6^{+}\right.$or $\mathrm{CD} 56^{+}$or both) subpopulations between the infants at the various times in their first year of life and the adults.

A lysed whole blood microassay was used for all stainings as described previously (10). Briefly, $20 \mu \mathrm{L}$ of blood was incubated with three optimally titrated MAb for $10 \mathrm{~min}$ at room temperature. Erythrocytes were lysed with Lysing Solution (Becton Dickinson, San Jose, CA). The CD71/glycophorin A/CD45 triple immunostaining was included to identify nor-

Table 1. Thirty triple immunostainings used in the longitudinal study

\begin{tabular}{|c|c|c|c|c|c|}
\hline Marker & $\begin{array}{l}\text { FITC conjugated } \\
\text { MAb (company)* }\end{array}$ & Marker & $\begin{array}{l}\text { PE conjugated MAb } \\
\text { (company) }\end{array}$ & Marker & $\begin{array}{l}\text { PE-Cy5 conjugated } \\
\text { MAb (company) }\end{array}$ \\
\hline IgG1 & IgG1 (BD) & $\mathrm{IgG} 2$ & $\mathrm{IgG} 2$ (BD) & IgG1 & $679.1 \mathrm{Mc} 7$ (IT) \\
\hline CD15 & CLB-gran2 (CLB) & CD14 & My-4 (CT) & CD45 & HI30 (PH) \\
\hline CD37 & IOB1 (IT) & CD20 & Leu-16 (BD) & CD19 & HIB19 (PH) \\
\hline CD5 & Leu-1 (BD) & CD19 & Leu-12 (BD) & CD3 & Hit3a (PH) \\
\hline CD38 & IOB6 (IT) & CD45RA & 2H4 (CT) & CD19 & HIB19 (PH) \\
\hline $\mathrm{CD} 25$ & $2 \mathrm{~A} 3(\mathrm{BD})$ & CD19 & Leu-12 (BD) & CD3 & Hit3a (PH) \\
\hline CD71 & 66IG10 (MS) & CD19 & Leu-12 (BD) & CD3 & Hit3a (PH) \\
\hline CD4 & Leu-3a (BD) & CD8 & Leu-2a (BD) & CD3 & Hit3a (PH) \\
\hline $\operatorname{TCR} \alpha \beta$ & WT31 (BD) & CD4 & Leu-3a (BD) & CD3 & Hit3a (PH) \\
\hline $\operatorname{TCR} \alpha \beta$ & WT31 (BD) & CD8 & Leu-2a (BD) & $\mathrm{CD} 3$ & Hit3a (PH) \\
\hline $\mathrm{TCR} \gamma \delta$ & TCR $\delta 1$ (TD) & CD4 & Leu-3a (BD) & CD3 & Hit3a (PH) \\
\hline CD8 & Leu-2a (BD) & $\mathrm{CD} 45 \mathrm{RO}$ & UCHL-1 (DK) & CD3 & Hit3a (PH) \\
\hline CD45RO & UCHL-1 (DK) & CD45RA & $2 \mathrm{H} 4(\mathrm{CT})$ & $\mathrm{CD} 3$ & Hit3a (PH) \\
\hline CD38 & IOB6 (IT) & CD45RO & UCHL-1 (DK) & CD3 & Hit3a (PH) \\
\hline CD38 & IOB6 (IT) & CD45RA & $2 \mathrm{H} 4(\mathrm{CT})$ & CD3 & Hit3a (PH) \\
\hline CD57 & Leu-7 (BD) & CD16/CD56 & Leu-11c/Leu-19 (BD) & CD3 & Hit3a (PH) \\
\hline CD7 & CLB3A1/1 (CLB) & CD16/CD56 & Leu-11c/Leu-19 (BD) & CD3 & Hit3a (PH) \\
\hline CD8 & Leu-2a (BD) & CD16/CD56 & Leu-11c/Leu-19 (BD) & CD3 & Hit3a (PH) \\
\hline CD38 & IOB6 (IT) & CD16/CD56 & Leu-11c/Leu-19 (BD) & CD3 & Hit3a (PH) \\
\hline CD45RO & UCHL-1 (DK) & CD16/CD56 & Leu-11c/Leu-19 (BD) & CD3 & Hit3a (PH) \\
\hline CD45RA & Leu-18 (BD) & CD16/CD56 & Leu-11c/Leu-19 (BD) & $\mathrm{CD} 3$ & Hit3a (PH) \\
\hline $\mathrm{CD} 25$ & $2 \mathrm{~A} 3(\mathrm{BD})$ & CD16/CD56 & Leu-11c/Leu-19 (BD) & CD3 & Hit3a (PH) \\
\hline HLA-DR & L243 (BD) & CD16/CD56 & Leu-11c/Leu-19 (BD) & CD3 & Hit3a (PH) \\
\hline
\end{tabular}

Abbreviations: PE, phycoerythrin; PE-Cy5, phycoerythrin-cyanin 5.

* Companies: BD = Becton Dickinson, San Jose, CA; CLB = Central Laboratory of the Blood Transfusion Service, Amsterdam, the Netherlands; MS =

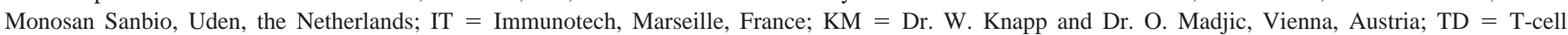
diagnostics, Cambridge, MA; DK = Dakopatts, Glostrup, Denmark; CT = Coulter Clone, Hialeah, FL; PH = Pharmingen, San Diego, CA. 
moblasts and unlysed erythrocytes within the lympho-gate, which was defined on the forward and side scatter patterns of lymphocytes (10). The samples were analyzed with a FACScan flow cytometer, using FACScan Research software (Becton Dickinson, San Jose, CA).

Lymphocyte count and differentiation. The total nucleated cell count was determined on an H1 Technicon hemocytometer (Bayer, Tarrytown, NY). The relative frequency of normoblasts was determined by manual differentiation of 400 nucleated cells in all samples. The total lymphocyte count was determined according to the following formula:

total nucleated cell count $\times$

$$
(100-\% \text { of normoblasts }) \times(\% \text { of lymphocytes }) \times 10^{-4}
$$

Lymphocyte subpopulations were calculated according to the following formula:

$$
\begin{aligned}
& \% \text { of population within the lympho-gate } \\
& \begin{array}{c}
100-(\% \text { of normoblasts plus unlysed } \\
\text { erythrocytes within the lympho-gate })
\end{array}
\end{aligned} \times 10^{2}
$$

Statistics. After applying logarithmic transformation to obtain approximately normally distributed variables, repeated measurements ANOVA was used to compare the various sampling times. Additional specific comparisons were made for T lymphocytes, NK cells, and their subpopulations in cord blood versus the mean of these variables at the other sampling times. Also, for B lymphocytes and their subpopulations, the mean of cord blood and blood drawn at 1 wk was compared with the mean of the sampling times thereafter. To evaluate the effects of infection, vaccination, medication, and breastfeeding at the various sampling times, the $t$ test was used for each factor. In view of the number of comparisons made, the significance level was set at $p<0.01$.

\section{RESULTS}

Subject follow-up. All infants were born after a normal pregnancy and delivery. All had birth weights appropriate for gestational age. None of the infants used medication at any time when a blood sample was taken. Several infants suffered from minor infections of the upper airways or gastrointestinal tract around the time a blood sample was taken. One infant had atopic eczema and food allergies (infant 5). No other medical problems were noted. The infants were vaccinated according to the regular Dutch schedule, which consisted of diphtheria toxoid, tetanus toxoid, pertussis, and inactivated polio virus type I, II, and III (DTP-IPV) at 3, 4, 5, and 11 mo of age at the time of the study.

Lymphocyte counts. Total lymphocyte counts and $\mathrm{T}$ lymphocyte counts increased at $1 \mathrm{wk}$ of age. B lymphocyte counts increased at $6 \mathrm{wk}$ of age. NK cells followed a different pattern: they were highest at birth and decreased at $1 \mathrm{wk}$ of age (Fig. 1 and Tables 2-4).

TCR expression on T lymphocytes. Most $\mathrm{T}$ lymphocytes expressed the $\alpha \beta$ TCR (Table 5). TCR $\gamma \delta^{+}$T lymphocyte counts increased slightly during the first year of life (Table 2).

Expression of CD4 and CD8 on T lymphocytes. CD4 ${ }^{+}$ helper $\mathrm{T}$ lymphocyte counts followed the pattern of total $\mathrm{T}$ lymphocyte counts with an increase at 1 wk of age, as did $\mathrm{CD}{ }^{+}$cytotoxic $\mathrm{T}$ lymphocyte counts (Table 2 ). Although both $\mathrm{CD} 4^{+} / \mathrm{CD}^{+}$and $\mathrm{CD} 8^{+} / \mathrm{CD}^{+}$counts were higher in infants than in adults, the CD4/CD8 ratio was higher in infants than in adults, because of the very high $\mathrm{CD} 4^{+} / \mathrm{CD}^{+}$counts in infants (Tables 2 and 5).

Paucity of thymocyte-like T cells. In the thymus, $\mathrm{CD}^{+} /$ $\mathrm{CD}^{+}$double-positive $\mathrm{T}$ cells develop into single-positive $\mathrm{CD}^{+}{ }^{+}$or $\mathrm{CD}^{+}{ }^{+} \mathrm{T}$ lymphocytes (11), and CD1a is a marker present on cortical thymocytes (12). Hardly any $\mathrm{CD} 4^{+} / \mathrm{CD} 8^{+}$ double-positive or $\mathrm{CD} 1 \mathrm{a}^{+} \mathrm{T}$ cells were present in the blood of either infants or adults (Fig. 2, $A-D$, and Tables 2 and 5).

CD45 isoform expression on T lymphocytes. The relative expression of the CD45RA and CD45RO isoforms was profoundly different between infants and adults: the median relative frequencies of $\mathrm{CD} 45 \mathrm{RA}^{+}$naive $\mathrm{T}$ lymphocytes were higher, and the median relative frequencies of $\mathrm{CD} 45 \mathrm{RO}^{+}$ memory $\mathrm{T}$ lymphocytes were lower, in infants than in adults (Table 5), as was described before $(3-5,13)$. However, the median absolute counts of $\mathrm{CD} 45 \mathrm{RO}^{+}$memory $\mathrm{T}$ lymphocytes were similar in infants and adults, with a slight increase at $1 \mathrm{wk}$ of age (Table 2). The changes in the absolute counts of $\mathrm{T}$ lymphocytes during the first year of life were mainly accounted for by changes in the size of the $\mathrm{CD}_{4} \mathrm{RA}^{+}$naive $\mathrm{T}$ lympho-

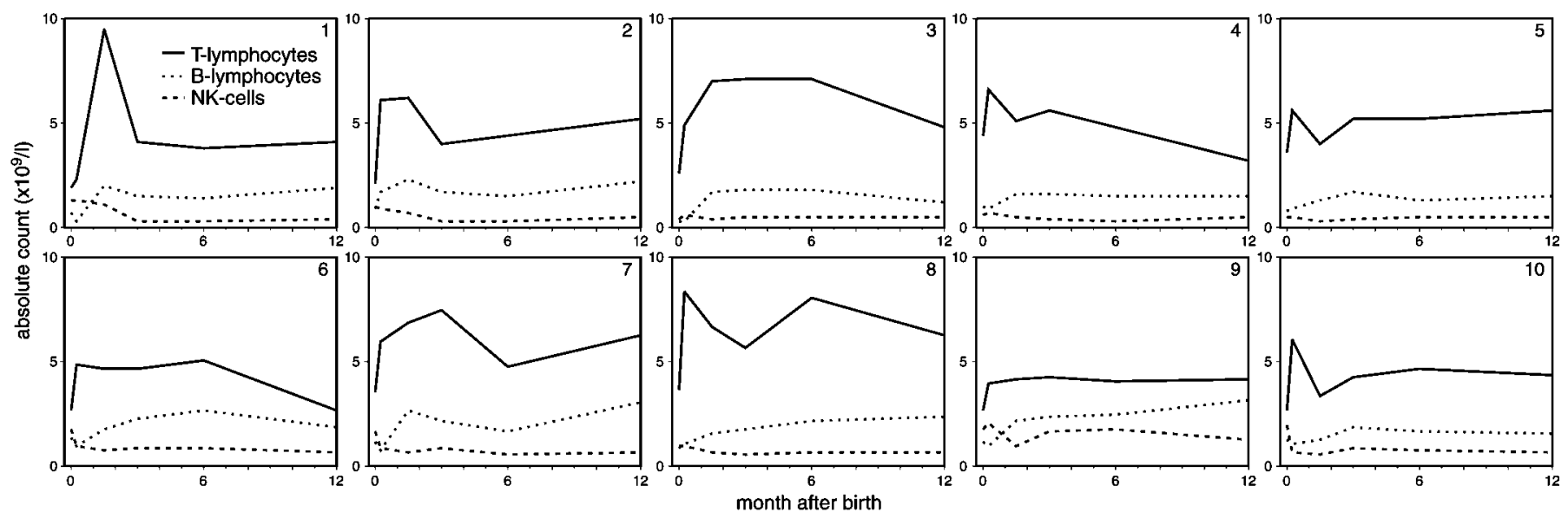

Figure 1. T lymphocytes, B lymphocytes, and NK cells from birth to 1 y of age. Each graph represents one individual infant (infants 1-10). 
Table 2. Absolute counts of lymphocytes, $C D 3^{+}$T lymphocytes, and $C D 3^{+}$T lymphocyte subpopulations in 11 infants during follow-up from birth to 1 y of age and in nine adults

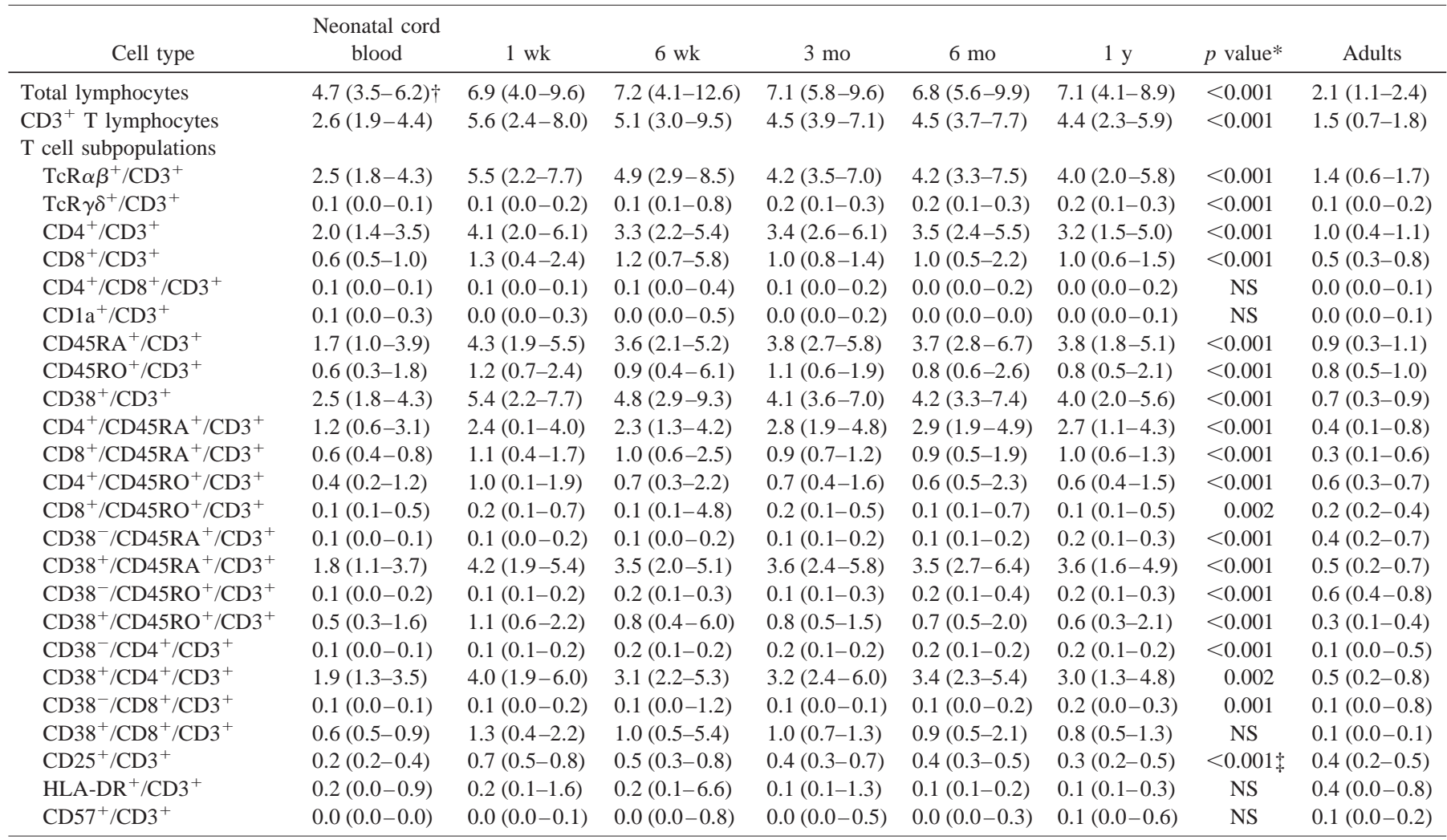

$\dagger$ Median absolute count followed by minimal and maximal absolute count in parentheses $\times 10^{9} / \mathrm{L}$.

$\ddagger$ also $1 \mathrm{wk}>6 \mathrm{wk}-1 \mathrm{y}, 6 \mathrm{wk}>3 \mathrm{mo}-1 \mathrm{y}, 3 \mathrm{mo}>6$ mo-1 y, all $p<0.001$.

* Neonatal cord blood $<1 \mathrm{wk}, 6 \mathrm{wk}, 1 \mathrm{mo}, 3 \mathrm{mo}, 6 \mathrm{mo}$, and $1 \mathrm{y}$.

Table 3. Absolute counts of $C D 19^{+}$B lymphocytes and $C D 19^{+}$B lymphocyte subpopulations in 11 infants during follow-up from birth to 1 y of age and in nine adults

\begin{tabular}{|c|c|c|c|c|c|c|c|c|}
\hline Cell type & $\begin{array}{c}\text { Neonatal cord } \\
\text { blood }\end{array}$ & $1 \mathrm{wk}$ & $6 \mathrm{wk}$ & $3 \mathrm{mo}$ & $6 \mathrm{mo}$ & $1 \mathrm{y}$ & $p$ value* & Adults \\
\hline $\mathrm{CD} 19^{+}$B lymphocytes & $0.8(0.3-1.0) \dagger$ & $0.6(0.3-1.7)$ & $1.6(0.9-2.4)$ & $1.7(1.4-2.0)$ & $1.4(1.3-2.3)$ & $1.7(1.2-2.8)$ & $<0.001$ & $0.2(0.1-0.4)$ \\
\hline \multicolumn{9}{|l|}{ B cell subpopulations } \\
\hline $\mathrm{CD} 1 \mathrm{c}^{+} / \mathrm{CD} 19^{+}$ & $0.6(0.3-0.9)$ & $0.5(0.2-1.6)$ & $1.1(0.7-1.9)$ & $1.2(0.9-1.5)$ & $0.9(0.6-1.3)$ & $0.9(0.7-1.4)$ & $<0.001$ & $0.1(0.0-0.1)$ \\
\hline $\mathrm{CD} 1 \mathrm{c}^{-} / \mathrm{CD} 19^{+}$ & $0.4(0.2-0.9)$ & $0.1(0.1-0.2)$ & $0.4(0.2-0.9)$ & $0.5(0.3-0.7)$ & $0.5(0.4-1.2)$ & $0.8(0.4-1.3)$ & $<0.001$ & $0.2(0.1-0.2)$ \\
\hline $\mathrm{CD}^{+} / \mathrm{CD} 19^{+}$ & $0.3(0.1-0.4)$ & $0.3(0.1-0.8)$ & $0.9(0.6-1.6)$ & $0.8(0.6-1.2)$ & $0.7(0.4-1.2)$ & $0.7(0.4-1.7)$ & $<0.001$ & $0.1(0.0-0.1)$ \\
\hline $\mathrm{CD} 38^{-} / \mathrm{CD} 19^{+}$ & $0.0(0.0-0.0)$ & $0.0(0.0-0.1)$ & $0.0(0.0-0.1)$ & $0.1(0.0-0.1)$ & $0.1(0.0-0.1)$ & $0.2(0.0-0.3)$ & NS & $0.0(0.0-0.1)$ \\
\hline $\mathrm{CD} 71^{+} / \mathrm{CD} 19^{+}$ & $0.0(0.0-0.4)$ & $0.0(0.0-0.1)$ & $0.0(0.0-0.1)$ & $0.1(0.0-0.1)$ & $0.1(0.0-0.2)$ & $0.1(0.0-0.1)$ & NS & $0.0(0.0-0.1)$ \\
\hline $\mathrm{CD} 25^{+} / \mathrm{CD} 19^{+}$ & $0.0(0.0-0.1)$ & $0.0(0.0-0.1)$ & $0.1(0.0-0.2)$ & $0.1(0.0-0.1)$ & $0.0(0.0-0.2)$ & $0.1(0.0-0.2)$ & NS & $0.2(0.0-0.5)$ \\
\hline
\end{tabular}

$\dagger$ Median absolute count followed by minimal and maximal absolute count in parentheses $\times 10^{9} / \mathrm{L}$.

* Neonatal cord blood, $1 \mathrm{wk}<6 \mathrm{wk}, 1 \mathrm{mo}, 3 \mathrm{mo}, 6 \mathrm{mo}$, and $1 \mathrm{y}$.

cyte population, not by changes in the size of the $\mathrm{CD} 45 \mathrm{RO}^{+}$ memory $\mathrm{T}$ lymphocyte population in the course of time (Figs. 3 and 4). However, the intensity of CD45RO staining was higher in adults than in infants, i.e. adult $\mathrm{T}$ lymphocytes probably carried more $\mathrm{CD} 45 \mathrm{RO}$ molecules on their cell surface (Fig. 2, $E$ and $F$ ).

The increase in $\mathrm{CD} 45 \mathrm{RA}^{+}$naive $\mathrm{T}$ lymphocytes during the first year of life and the slight increase of $\mathrm{CD} 45 \mathrm{RO}^{+}$memory $\mathrm{T}$ lymphocytes at $1 \mathrm{wk}$ of age was caused by an increase in $\mathrm{CD}^{+}{ }^{+}$helper $\mathrm{T}$ lymphocytes as well as $\mathrm{CD}^{+}$cytotoxic $\mathrm{T}$ lymphocytes (Tables 2 and 5).
Expression of CD38 on T lymphocytes. We found CD38 on $\geq 90 \%$ (median) of T lymphocytes in infants, and on about half of adult T lymphocytes (Fig. 2, $G$ and $H$, and Table 5).

The distribution of $\mathrm{CD} 38$ on $\mathrm{CD}^{2} 5 \mathrm{RA}^{+}$naive and

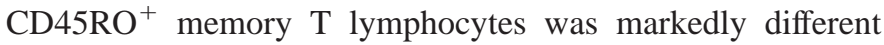
between infants and adults (Table 5). In adults, the $\mathrm{CD}^{+} 8^{+} /$ $\mathrm{CD}^{2} 5 \mathrm{RA}^{+} / \mathrm{CD}^{+}{ }^{+}$and the $\mathrm{CD} 38^{+} / \mathrm{CD} 45 \mathrm{RO}^{+} / \mathrm{CD}^{+}$subpopulations were much smaller, and the $\mathrm{CD} 38^{-} / \mathrm{CD} 45 \mathrm{RA}^{+} / \mathrm{CD}^{+}$ and the $\mathrm{CD} 38^{-} / \mathrm{CD} 45 \mathrm{RO}^{+} / \mathrm{CD}^{+}$subpopulations were much larger, than in infants. The changes in size of the CD45RA ${ }^{+}$ naive $\mathrm{T}$ lymphocyte subpopulation in the first year of life were 
Table 4. Absolute counts of $C D 16^{+} / 56^{+} / C D 3^{-} \mathrm{NK}$ cells and $\mathrm{CD} 16^{+} / 56^{+} / \mathrm{CD} 3^{-} \mathrm{NK}$ cell subpopulations in 11 infants during follow-up from birth to 1 y of age and in nine adults

\begin{tabular}{|c|c|c|c|c|c|c|c|c|}
\hline Cell type & $\begin{array}{c}\text { Neonatal cord } \\
\text { blood }\end{array}$ & $1 \mathrm{wk}$ & $6 \mathrm{wk}$ & $3 \mathrm{mo}$ & $6 \mathrm{mo}$ & $1 \mathrm{y}$ & $p$ value* & Adults \\
\hline $\mathrm{CD} 16^{+} / 56^{+} / \mathrm{CD} 3^{-} \mathrm{NK}$ cells & $1.0(0.4-1.6) \dagger$ & $0.6(0.3-1.7)$ & $0.4(0.2-1.1)$ & $0.5(0.2-1.3)$ & $0.3(0.2-1.4)$ & $0.4(0.3-0.9)$ & $<0.001$ & $0.2(0.1-0.4)$ \\
\hline \multicolumn{9}{|l|}{ NK cell subpopulations } \\
\hline $\mathrm{CD} 5 \mathrm{RA}^{+} / \mathrm{CD} 16^{+} / 56^{+} / \mathrm{CD}^{-}-$ & $0.6(0.3-1.2)$ & $0.5(0.2-1.7)$ & $0.4(0.2-1.0)$ & $0.4(0.2-1.3)$ & $0.3(0.2-1.4)$ & $0.4(0.2-0.8)$ & NS & $0.2(0.1-0.3)$ \\
\hline $\mathrm{CD} 38^{+} / \mathrm{CD} 16^{+} / 56^{+} / \mathrm{CD} 3^{-}$ & $0.6(0.2-1.2)$ & $0.5(0.2-1.7)$ & $0.4(0.2-1.0)$ & $0.4(0.2-1.3)$ & $0.3(0.2-1.4)$ & $0.4(0.3-0.9)$ & NS & $0.2(0.1-0.3)$ \\
\hline $\mathrm{CD} 5 \mathrm{RO}^{+} / \mathrm{CD} 16^{+} / 56^{+} / \mathrm{CD}^{-}$ & $0.0(0.0-0.0)$ & $0.0(0.0-0.1)$ & $0.0(0.0-0.1)$ & $0.0(0.0-0.0)$ & $0.0(0.0-0.1)$ & $0.0(0.0-0.1)$ & NS & $0.0(0.0-0.0)$ \\
\hline $\mathrm{CD} 25^{+} / \mathrm{CD} 16^{+} / 56^{+} / \mathrm{CD}^{-}$ & $0.0(0.0-0.0)$ & $0.0(0.0-0.0)$ & $0.0(0.0-0.0)$ & $0.0(0.0-0.0)$ & $0.0(0.0-0.0)$ & $0.0(0.0-0.0)$ & NS & $0.0(0.0-0.0)$ \\
\hline 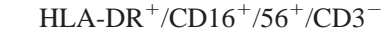 & $0.0(0.0-0.2)$ & $0.0(0.0-0.2)$ & $0.1(0.0-0.4)$ & $0.0(0.0-0.1)$ & $0.0(0.0-0.1)$ & $0.0(0.0-0.1)$ & NS & $0.0(0.0-0.1)$ \\
\hline
\end{tabular}

$\dagger$ Median absolute count followed by minimal and maximal absolute count in parentheses $\times 10^{9} / \mathrm{L}$.

* Neonatal cord blood > $1 \mathrm{wk}, 6 \mathrm{wk}, 3 \mathrm{mo}, 6 \mathrm{mo}$, and $1 \mathrm{y}$.

Table 5. Relative frequencies of $\mathrm{CD}^{+}$T lymphocytes and $C D 3^{+}$T lymphocyte subpopulations in 11 infants during follow-up from birth to 1 y of age and in nine adults

\begin{tabular}{|c|c|c|c|c|c|c|c|}
\hline Cell type & $\begin{array}{l}\text { Neonatal cord } \\
\text { blood }\end{array}$ & $1 \mathrm{wk}$ & $6 \mathrm{wk}$ & $3 \mathrm{mo}$ & $6 \mathrm{mo}$ & $1 \mathrm{y}$ & Adults \\
\hline $\mathrm{CD}^{+}{ }^{+} \mathrm{T}$ lymphocytes & $59(44-76)^{*}$ & $79(58-89)$ & $71(61-80)$ & $69(53-76)$ & $72(50-78)$ & $65(50-73)$ & $72(60-83)$ \\
\hline \multicolumn{8}{|l|}{$\mathrm{T}$ cell subpopulations } \\
\hline $\mathrm{TCR} \gamma \delta^{+}$ & $3(1-4)$ & $2(0-3)$ & $3(1-9)$ & $3(1-6)$ & $4(1-6)$ & $4(2-8)$ & $5(2-15)$ \\
\hline $\mathrm{CD} 4^{+}$ & $72(62-82)$ & $76(69-87)$ & $74(35-84)$ & $75(63-86)$ & $56(34-64)$ & $50(30-62)$ & $58(52-69)$ \\
\hline $\mathrm{CD} 8^{+}$ & $27(17-35)$ & $25(13-31)$ & $25(15-61)$ & $15(10-34)$ & $15(8-32)$ & $16(8-34)$ & $33(27-46)$ \\
\hline $\mathrm{CD}_{1} \mathrm{a}^{+}$ & $2(0-7)$ & $1(0-5)$ & $1(0-5)$ & $1(0-4)$ & $0(0-1)$ & $0(0-1)$ & $0(0-2)$ \\
\hline $\mathrm{CD} 45 \mathrm{RA}^{+}$ & $72(44-94)$ & $79(52-90)$ & $69(52-84)$ & $74(67-91)$ & $80(64-90)$ & $81(72-88)$ & $60(46-71)$ \\
\hline $\mathrm{CD}_{45 \mathrm{RO}^{+}}$ & $23(10-76)$ & $26(16-65)$ & $17(9-74)$ & $18(14-50)$ & $15(13-71)$ & $16(9-54)$ & $56(48-71)$ \\
\hline $\mathrm{CD} 38^{+}$ & $95(92-98)$ & $96(95-98)$ & $95(91-98)$ & $95(90-98)$ & $93(89-96)$ & $90(87-95)$ & $45(34-62)$ \\
\hline $\mathrm{CD}^{+}{ }^{+} / \mathrm{CD} 45 \mathrm{RA}^{+}$ & $70(37-95)$ & $76(41-88)$ & $65(57-81)$ & $79(64-96)$ & $82(72-91)$ & $80(65-97)$ & $49(35-70)$ \\
\hline $\mathrm{CD}^{+} / \mathrm{CD} 45 \mathrm{RA}^{+}$ & $83(59-99)$ & $84(67-97)$ & $83(42-93)$ & $84(73-99)$ & $89(84-94)$ & $89(81-100)$ & $73(55-80)$ \\
\hline $\mathrm{CD} 8^{-} / \mathrm{CD} 45 \mathrm{RO}^{+}$ & $9(4-19)$ & $8(5-13)$ & $14(2-26)$ & $17(9-29)$ & $23(14-30)$ & $23(13-36)$ & $74(58-83)$ \\
\hline $\mathrm{CD}_{38}{ }^{+} / \mathrm{CD} 45 \mathrm{RO}^{+}$ & $91(81-94)$ & $90(87-94)$ & $87(74-98)$ & $83(71-92)$ & $77(71-85)$ & $77(64-93)$ & $28(16-42)$ \\
\hline $\mathrm{CD} 38^{-} / \mathrm{CD} 4^{+}$ & $2(1-5)$ & $2(1-4)$ & $3(2-6)$ & $3(2-5)$ & $3(2-5)$ & $4(2-7)$ & $27(17-33)$ \\
\hline $\mathrm{CD} 38^{+} / \mathrm{CD} 4^{+}$ & 98 (94-99) & 98 (94-99) & $96(93-98)$ & $96(92-98)$ & $96(92-97)$ & $94(90-96)$ & $52(42-75)$ \\
\hline $\mathrm{CD} 38^{-} / \mathrm{CD}^{+}$ & $2(1-4)$ & $1(1-3)$ & $1(1-3)$ & $2(0-7)$ & $2(0-4)$ & $4(1-7)$ & $26(15-33)$ \\
\hline $\mathrm{CD} 38^{+} / \mathrm{CD}^{+}$ & $93(90-97)$ & $96(92-97)$ & 95 (90-99) & 93 (85-97) & $92(84-97)$ & $83(77-95)$ & $32(21-54)$ \\
\hline $\mathrm{CD} 25^{+}$ & $10(6-15)$ & $13(10-21)$ & $9(8-12)$ & $9(8-11)$ & $9(6-11)$ & $8(6-10)$ & $27(19-36)$ \\
\hline HLA-DR $^{+}$ & $9(1-30)$ & $3(1-27)$ & $4(2-70)$ & $3(2-31)$ & $3(2-6)$ & $3(2-7)$ & $28(3-45)$ \\
\hline $\mathrm{CD} 7^{+}$ & $0(0-1)$ & $0(0-1)$ & $1(0-8)$ & $1(0-12)$ & $1(0-8)$ & $2(1-14)$ & $7(2-17)$ \\
\hline
\end{tabular}

* Median relative frequency followed by minimal and maximal relative frequency between parentheses within the lymphocyte population.

$\dagger \%$ positivity of the $\mathrm{CD}^{+} \mathrm{T}$ lymphocyte subpopulation followed by minimal and maximal values between parentheses.

mainly caused by changes in size of the $\mathrm{CD}^{+} 8^{+} / \mathrm{CD} 45 \mathrm{RA}^{+} /$ $\mathrm{CD}^{+}$subpopulation. The median absolute counts of $\mathrm{CD}^{+} 8^{-} /$ $\mathrm{CD} 4 \mathrm{RO}^{+} / \mathrm{CD}^{+}{ }^{\mathrm{T}}$ lymphocytes increased only slightly during the first year of life. The slight peak of $\mathrm{CD} 45 \mathrm{RO}^{+}$memory $\mathrm{T}$ lymphocytes at $1 \mathrm{wk}$ of age was mainly caused by an increase in $\mathrm{CD}_{3} 8^{+} / \mathrm{CD} 45 \mathrm{RO}^{+} / \mathrm{CD}^{+}{ }^{+} \mathrm{T}$ lymphocytes (Table 2).

The expression of CD38 on $\mathrm{CD}^{+}{ }^{+}$helper $\mathrm{T}$ lymphocytes and on $\mathrm{CD}^{+}$cytotoxic $\mathrm{T}$ lymphocytes was also different between infants and adults (Table 5). In adults, most $\mathrm{CD} 8^{+} \mathrm{T}$ lymphocytes were $\mathrm{CD} 38^{-}$, whereas about half of the $\mathrm{CD} 4^{+} \mathrm{T}$ lymphocytes could be classified as $\mathrm{CD} 38^{+}$. The changes in $\mathrm{CD}^{+} \mathrm{T}$ lymphocytes in the first year of life were mainly caused by changes in the size of the $\mathrm{CD} 38^{+} / \mathrm{CD} 4^{+} / \mathrm{CD} 3^{+}$ subpopulation, not by changes in the size of the $\mathrm{CD} 38^{-} / \mathrm{CD}^{+} /$ $\mathrm{CD}^{+}$subpopulation (Table 2).

Expression of CD25 and HLA-DR on T lymphocytes. The absolute counts of $\mathrm{T}$ lymphocytes bearing CD25 (the IL-2 receptor $\alpha$-chain) on their surface peaked at $1 \mathrm{wk}$ of age. The absolute counts of HLA-DR ${ }^{+} \mathrm{T}$ lymphocytes did not. They were lower than in adults throughout the first year of life (Table 2).

Absence of $\mathrm{CD}^{+} 7^{+}$T lymphocytes. The human NK cell antigen, CD57, is present on a subpopulation of T lymphocytes. It has been suggested that these cells represent previously activated $\mathrm{T}$ lymphocytes, which have returned to a state 

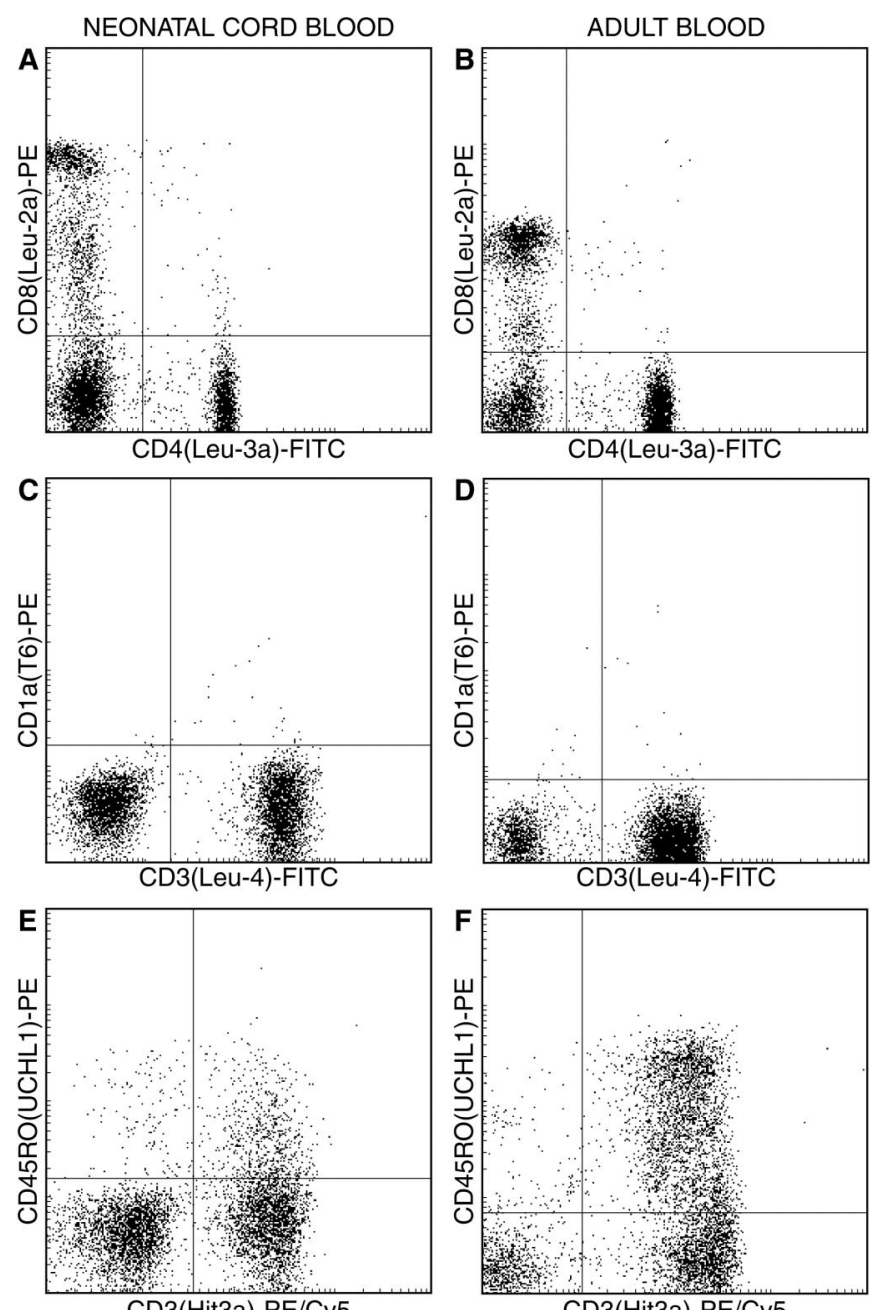

CD3(Hit3a)-PE/Cy5

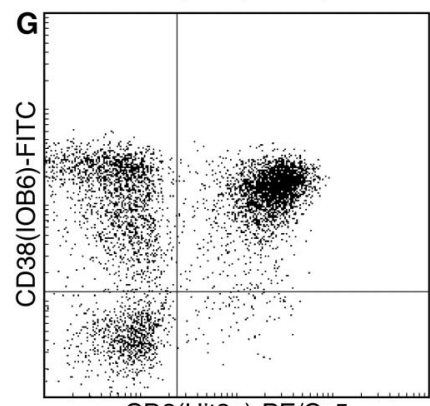

CD3(Hit3a)-PE/Cy5

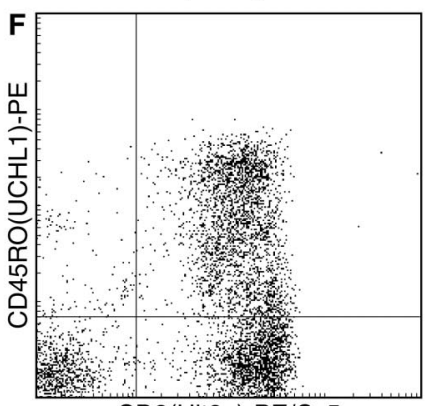

CD3(Hit3a)-PE/Cy5

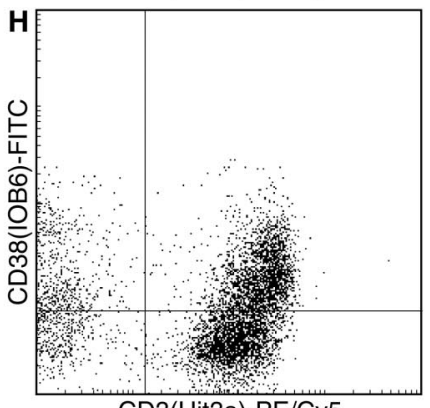

CD3(Hit3a)-PE/Cy5

Figure 2. Expression of early developmental markers and markers of maturation by $\mathrm{T}$ lymphocytes. Hardly any $\mathrm{CD} 4^{+} / \mathrm{CD} 8^{+}$double-positive $\mathrm{T}$ cells were present in neonates $(A)$ and adults $(B)$. CD1a was hardly expressed on $\mathrm{T}$ cells at birth $(C)$, or in adults $(D)$. The intensity of staining of $\mathrm{CD}^{2} 5 \mathrm{RO}^{+}$ memory $\mathrm{T}$ lymphocytes was lower in neonates $(E)$ than in adults $(F)$. CD38 was expressed by most $\mathrm{T}$ lymphocytes in neonates $(G)$, and by about half of adult $\mathrm{T}$ lymphocytes $(H)$.

of rest (13). $\mathrm{CD} 7^{+} \mathrm{T}$ lymphocytes were virtually absent at birth, and very low up to 6 mo of age, except for two infants who had higher values at some, but not all, sampling times (Tables 2 and 5).

Paucity of precursor B cells. There was no indication that B lymphocytes leave the bone marrow at an earlier developmental stage in infants than in adults: hardly any $\mathrm{CD} 37^{-} / \mathrm{CD} 20^{-} /$ $\mathrm{CD} 19^{+}$precursor $\mathrm{B}$ cells (14) were present in the samples of either infants or adults (Tables 3 and 6).

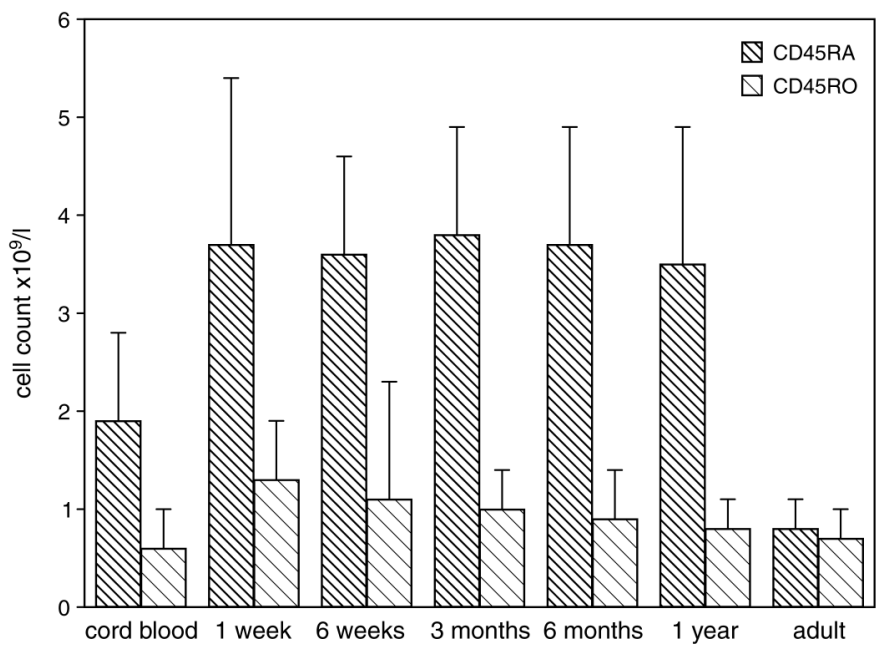

Figure 3. Absolute counts (geometric mean and SD) of $\mathrm{CD}_{45 \mathrm{RA}^{+}}$and $\mathrm{CD}^{2} 5 \mathrm{RO}^{+} \mathrm{T}$ lymphocyte subpopulations $\times 10^{9} / \mathrm{L}$ in 11 infants during the first year of life and in nine adults. Left bars, CD45RA ${ }^{+} \mathrm{T}$ lymphocytes. Right bars, CD45RO ${ }^{+} \mathrm{T}$ lymphocytes.

Expression of CD1c, CD5, and CD38 on B lymphocytes. The relative frequencies of $\mathrm{CD} 1 \mathrm{c}^{+}$and $\mathrm{CD} 5^{+} \mathrm{B}$ lymphocytes were higher in infants than in adults. $\mathrm{CD} 1 \mathrm{c}^{+}$and $\mathrm{CD}^{+} \mathrm{B}$ lymphocyte absolute counts followed the pattern of total B lymphocytes during the first year of life, with high values from 6 wk of age onward. The same was observed for $\mathrm{CD}^{-} \mathrm{c}^{-}$and $\mathrm{CD}^{-}$B lymphocyte absolute counts, although this was not statistically significant in the latter cell type (Fig. 5, Table 3). CD38 was present on a median of $>90 \%$ of B lymphocytes throughout the first year of life, and on a median of $82 \%$ of B lymphocytes in adults (Table 6). CD38 $8^{-}$B lymphocyte absolute counts were low in both infants and adults (generally $\left.<0.1 \times 10^{9} / \mathrm{L}\right)($ Table 3$)$.

Expression of CD25 on B lymphocytes. CD25 is a marker of activation in B lymphocytes (15).The relative frequencies and absolute counts of $\mathrm{CD} 25^{+} \mathrm{B}$ lymphocytes were lower during the first year of life than in adults (Tables 3 and 6).

Expression of CD71 on B lymphocytes. The transferrin receptor CD71 is present on a subpopulation of B lymphocytes (16). It is not clear what role CD71 has on the surface of B lymphocytes. It might be present as a marker of activation. The absolute counts of $\mathrm{CD} 71^{+}$B lymphocytes were the same in infants throughout the first year of life and in adults (Table 3). It is important to note that most $\mathrm{CD} 71^{+}$cells $(66-95 \%)$ within the lympho-gate of the neonatal cord blood samples were normoblasts, as we described before (10).

$\mathrm{CD}^{-}, \mathrm{CD}^{-} 8^{-}$, and CD45RA ${ }^{-} \mathrm{NK}$ cells. At birth, some infants showed large subpopulations of NK cells that were not expressing CD7, CD38, and CD45RA. At 1 wk of age, five of 11 , four of 11 , and three of 11 infants still did not express CD7, CD38, and CD45RA, respectively, on $>20 \%$ of their NK cells. However, the $\mathrm{CD}^{-}{ }^{-} \mathrm{CD}^{-} 8^{-}$, and $\mathrm{CD} 45 \mathrm{RA}^{-}$NK cells do not account for the high absolute NK cell counts during the first week of life (Table 7). Only $\mathrm{CD}^{+}$NK cells were significantly higher at birth than thereafter (see below).

Absence of ${\mathrm{CD} 57^{+}}^{\mathrm{NK}}$ cells. CD57 is a well-known marker of a subpopulation of NK cells, whose role is not yet known. 

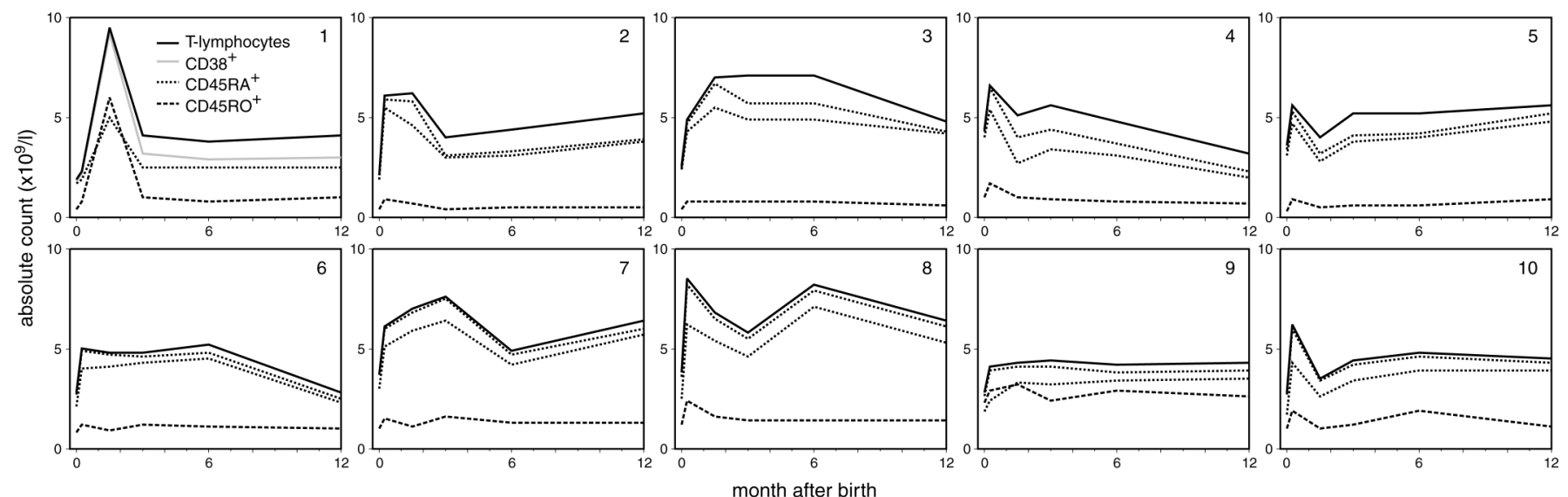

Figure 4. $\mathrm{CD} 45 \mathrm{RA}^{+}$and $\mathrm{CD} 38^{+} \mathrm{T}$ lymphocytes followed the pattern of total $\mathrm{T}$ lymphocytes in the infants, but $\mathrm{CD} 45 \mathrm{RO}^{+} \mathrm{T}$ lymphocytes did not. Each graph represents one individual infant (infants 1-10).

Table 6. Relative frequencies of $\mathrm{CD}_{1} 9^{+} \mathrm{B}$ lymphocytes and $\mathrm{CD} 19^{+}$B lymphocyte subpopulations in 11 infants during follow-up from birth to 1 y of age and in nine adults

\begin{tabular}{|c|c|c|c|c|c|c|c|}
\hline Cell type & $\begin{array}{l}\text { Neonatal } \\
\text { cord blood }\end{array}$ & $1 \mathrm{wk}$ & $6 \mathrm{wk}$ & $3 \mathrm{mo}$ & $6 \mathrm{mo}$ & $1 \mathrm{y}$ & Adults \\
\hline CD19 ${ }^{+}$B lymphocytes & $16(9-21)^{*}$ & $10(6-19)$ & $22(16-29)$ & $23(18-28)$ & $22(18-31)$ & $28(19-36)$ & $12(7-18)$ \\
\hline \multicolumn{8}{|l|}{ B cell subpopulation } \\
\hline $\mathrm{CD}^{+}$ & $38(25-62)$ & $47(40-67)$ & $62(48-71)$ & $45(34-73)$ & $43(30-68)$ & $48(29-68)$ & $23(13-30)$ \\
\hline $\mathrm{CD} 1 \mathrm{c}^{+}$ & $85(59-92)$ & $87(72-90)$ & $75(54-83)$ & $69(61-79)$ & $64(46-72)$ & $55(33-63)$ & $25(21-29)$ \\
\hline $\mathrm{CD} 8^{+}$ & $99(98-100)$ & $98(90-99)$ & $98(95-99)$ & $97(94-99)$ & $94(91-97)$ & $93(82-97)$ & $82(62-86)$ \\
\hline
\end{tabular}

* Median relative frequency followed by minimal and maximal relative frequency between parentheses within the lymphocyte population.

$\dagger \%$ positivity within the $\mathrm{CD} 19^{+} \mathrm{B}$ lymphocyte subpopulation followed by minimal and maximal values between parentheses.

It is rapidly lost after NK cell activation (17). Interestingly, CD57 was hardly expressed by NK cells until 3 mo of age (Fig. $6 A$ ). From 3 mo until 1 y of age, a growing number of infants showed a $\mathrm{CD}^{2} 7^{+} \mathrm{NK}$ cell subpopulation of up to approximately 20\% (median) of NK cells. Adults always showed a $\mathrm{CD} 7^{+}$NK cell subpopulation (Fig. $6 B$, Tables 4 and 7).

Absence of CD45RO ${ }^{+} \mathrm{NK}$ cells. The CD45RA ${ }^{-} \mathrm{NK}$ cells in neonatal cord blood must express another isoform of the CD45 molecule, such as CD45RB or CD45RC, inasmuch as almost none of these NK cells were expressing the CD45RO isoform either (Fig. 6C, Tables 4 and 7). Possibly the small but clearly present population of $\mathrm{CD} 45 \mathrm{RO}^{+}$NK cells in adults (Fig. $6 D$ ) represents NK cells that have encountered a stimulus, similar to $\mathrm{CD} 45 \mathrm{RO}^{+}$memory $\mathrm{T}$ lymphocytes.

Expression of CD25 and HLA-DR on NK cells. CD25 is up-regulated in NK cells on activation, as is HLA-DR (18). CD25 and HLA-DR were hardly expressed by NK cells in infants as well as adults (Tables 4 and 7).

Expression of CD8 on NK cells. The relative frequency of $\mathrm{CD}^{+}$NK cells did not change significantly during the first year of life (Table 7), but the absolute counts of $\mathrm{CD} 8^{+} \mathrm{NK}$ cells at birth and $1 \mathrm{wk}$ of age were high (Table 4). These high $\mathrm{CD} 8^{+} \mathrm{NK}$ cell counts can influence the determination of the $\mathrm{CD} 4^{+} / \mathrm{CD}^{+}{ }^{+}$ratio of $\mathrm{T}$ lymphocytes if single immunostaining is used instead of multiple immunostaining with $\mathrm{CD} 4, \mathrm{CD} 8$, and CD3 MAb.

Influence of infections and vaccinations. Infant 1 experienced her first, probably viral, upper respiratory tract infection at 6 wk of age; she was not very ill, and recovered without treatment within a week. None of the other infants had an infection in the first 6 wk of life. Infant 1 had a very high $\mathrm{T}$ lymphocyte count at week 6 (Fig. 1), because of an extremely high absolute count of $\mathrm{CD} 8^{+} \mathrm{T}$ lymphocytes $\left(5.8 \times 10^{9} / \mathrm{L}\right)$; her absolute count of $\mathrm{CD} 4^{+} \mathrm{T}$ lymphocytes was not different from that of other infants $\left(3.3 \times 10^{9} / \mathrm{L}\right)$. Her $\mathrm{CD} 45 \mathrm{RO}^{+}$memory $\mathrm{T}$ lymphocytes were high at that time $\left(6.1 \times 10^{9} / \mathrm{L}\right)$; there was no significant relation between the absolute count of CD45RO ${ }^{+}$ memory $\mathrm{T}$ lymphocytes and infection at any other time in our small group of infants, however. Interestingly, $\mathrm{CD} 25^{+} \mathrm{T}$ lymphocytes in infant 1 were not different from those of other infants $\left(9 \%\right.$ of $\mathrm{T}$ lymphocytes; $\left.0.8 \times 10^{9} / \mathrm{L}\right)$, whereas the HLA-DR $^{+} \mathrm{T}$ lymphocyte count was very high $(70 \%$ of $\mathrm{T}$ lymphocytes; $6.6 \times 10^{9} / \mathrm{L}$ ), as was the HLA-DR ${ }^{+} \mathrm{NK}$ cell count $\left(40 \%\right.$ of NK cells, $\left.0.5 \times 10^{9} / \mathrm{L}\right)$.

At no other time was a significant relation between recent infection or vaccination and the distribution of lymphocyte subpopulations found in this small group of 11 infants.

\section{DISCUSSION}

After differentiation in the bone marrow and thymus, lymphocytes undergo further functional maturation in the periphery. This process is directed by numerous encounters with environmental antigens that take place from birth onward. The immune system thus gradually builds up a pool of experienced memory lymphocytes. It is to be expected that these matura- 

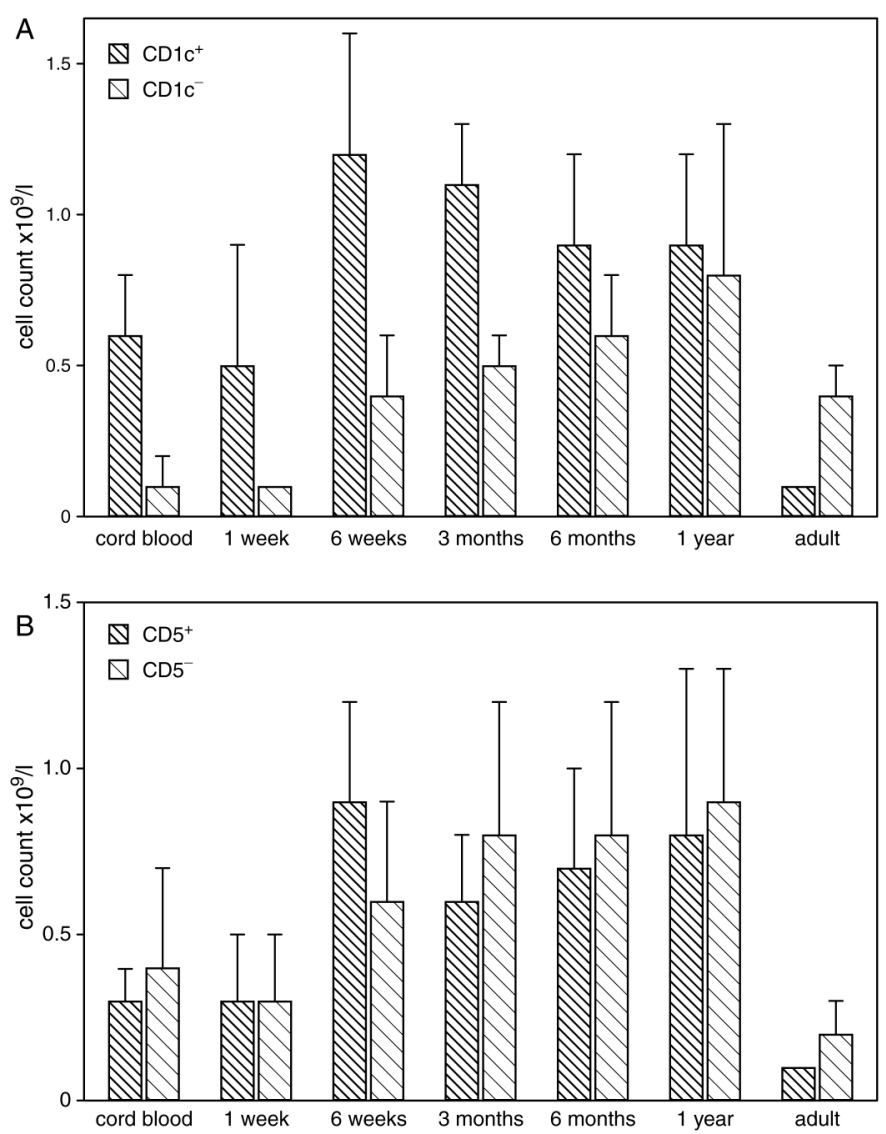

Figure 5. Absolute counts (geometric mean and SD) of various B lymphocyte subpopulations $\times 10^{9} / \mathrm{L}$ in 11 infants during the first year of life and in nine adults. A, left bars, CD1c ${ }^{+} \mathrm{B}$ lymphocytes; right bars, $\mathrm{CD} 1 \mathrm{c}^{-} \mathrm{B}$ lymphocytes. $B$, left bars, $\mathrm{CD}^{+} \mathrm{B}$ lymphocytes; right bars, $\mathrm{CD} 5^{-} \mathrm{B}$ lymphocytes.

tional processes are to some extent reflected by changes in the composition of lymphocyte subpopulations during infancy.

Reference values for lymphocyte subpopulations obtained in cross-sectional studies may reflect this gradual process, but changes in the composition of lymphocyte subpopulations in individual children will not occur at exactly the same sampling times in life, and will therefore be leveled off in such studies. Longitudinal studies in individual children are more informative about the pattern of lymphocyte subpopulation development as a function of time, and about the influences of external factors, such as infections and vaccinations, on this development. Also, children with immune disorders are generally followed longitudinally. Therefore, we performed a longitudinal survey of lymphocyte subpopulations in 11 healthy infants during the first year of life and compared these results with those obtained in nine adults. We did not find a significant relation between infection or vaccination and the distribution of lymphocyte subpopulations-except for one sampling time-in this small group of 11 healthy infants.

We found that $\mathrm{T}$ and $\mathrm{B}$ lymphocyte counts were high throughout the first year of life, with an increase at 1 and $6 \mathrm{wk}$ of age, respectively. In contrast, NK cell counts were high at birth and declined after the first week of life, but remained at levels about twice those found in adults. This is in line with previous data obtained in a cross-sectional study, as we reported recently (19).
Because of these high lymphocyte counts in infants, differences in subpopulations of T and B lymphocytes and NK cells between infants and adults are better reflected by comparison of their absolute counts than by comparison of their relative frequencies. This is illustrated by our findings in $\mathrm{T}$ and $\mathrm{B}$ lymphocyte, as well as NK cell, subpopulations.

$\mathrm{CD}^{+}{ }^{+}$as well as $\mathrm{CD}^{+} \mathrm{T}$ lymphocyte counts followed the pattern of total $\mathrm{T}$ lymphocytes, with an increase at $1 \mathrm{wk}$ of age and high numbers-especially of $\mathrm{CD} 4^{+} / \mathrm{CD}^{+} \mathrm{T}$ lymphocytes-throughout the first year of life. These were mainly $\mathrm{CD}_{45 \mathrm{RA}^{+}}$naive $\mathrm{T}$ lymphocytes, probably new $\mathrm{T}$ cells freshly released from the thymus (20). The absolute counts of $\mathrm{CD}_{45 \mathrm{RO}^{+}}$memory $\mathrm{T}$ lymphocytes in infants during the first year of life and in adults were similar. Therefore, the profound differences in relative frequencies of $\mathrm{CD}_{45 \mathrm{RA}}{ }^{+}$naive and $\mathrm{CD}_{45 \mathrm{RO}^{+}}$memory $\mathrm{T}$ lymphocytes between infants and adults are not caused by changes in the size of the $\mathrm{CD}_{45 \mathrm{RO}^{+}}$memory pool, but by changes in the size of the $\mathrm{CD}^{4} 5 \mathrm{RA}^{+}$naive pool of T lymphocytes: a large pool of naive untriggered cells is present at birth, and increases further during the first year of life, ready for participation in primary immune responses.

Then how is the building of a functional memory pool of $\mathrm{T}$ lymphocytes reflected in the distribution of $\mathrm{T}$ lymphocyte subpopulations? First, adult $\mathrm{T}$ lymphocytes probably carried more CD45RO molecules on their surface than infant $\mathrm{T}$ lymphocytes. Second, the distribution of the expression of CD38 on $\mathrm{CD}_{45 \mathrm{RO}^{+}}$memory (and $\mathrm{CD}^{+} 5 \mathrm{RA}^{+}$naive) $\mathrm{T}$ lymphocytes was markedly different between infants and adults: it decreased from birth to adulthood, as was described before on total $\mathrm{T}$ lymphocytes $(4,21-27)$. CD38 is a differentiation lineageunrestricted cell surface molecule, with a role in cellular adhesion, activation, and proliferation, known to be expressed on thymocytes, activated peripheral blood $\mathrm{T}$ and $\mathrm{B}$ lymphocytes, and plasma cells. It is generally regarded as an activation marker (28). However, we and others $(1,27,29,30)$ did not find other markers of activation in neonatal cord or infant blood, such as increased expression of CD25, HLA-DR, CD69, and CD154 (CD40 ligand). Nor did we find an increase of thymocyte-like $\mathrm{CD}_{1} \mathrm{a}^{+}$or $\mathrm{CD} 4^{+} / \mathrm{CD}^{+}$double-positive $\mathrm{T}$ cells. We therefore presume that the abundant expression of CD38 on infant's T lymphocytes might be related to a greater metabolic need of the large population of naive untriggered cells, because of their continually required participation in primary immune responses.

Little is known about markers expressed by naive untriggered B lymphocytes. Cell surface expression of CD45 isoforms is not informative in B lymphocytes: all B lymphocytes express the CD45RA isoform (31), not the CD45RO isoform (32). We and others (16) found higher relative frequencies of $\mathrm{CD}_{1 c^{+}}, \mathrm{CD}^{+}$, and $\mathrm{CD}^{+} 8^{+} \mathrm{B}$ lymphocytes in neonates and infants than in adults. The function of CD1c on the surface of B lymphocytes has not yet been elucidated. $\mathrm{CD}^{+} \mathrm{B}$ lymphocytes spontaneously produce low-affinity polyreactive IgM autoantibodies, use unmutated genes, and are presumed to represent a more primitive lineage than $\mathrm{CD}^{-} \mathrm{B}$ lymphocytes (33). We found that $\mathrm{CD}^{+}{ }^{+}$and $\mathrm{CD}^{+}$B lymphocyte counts were indeed higher at birth than in adults; they increased even further during the first year of life. $\mathrm{CD}^{-} \mathrm{c}^{-}$and $\mathrm{CD}^{-} \mathrm{B}$ 
Table 7. Relative frequencies of $C D 16^{+} / 56^{+} / C D 3^{-} \mathrm{NK}$ cells and $C D 16^{+} / 56^{+} / C D 3^{-} \mathrm{NK}$ cell subpopulations in 11 infants during follow-up from birth to 1 y of age and in nine adults

\begin{tabular}{|c|c|c|c|c|c|c|c|}
\hline Cell type & $\begin{array}{l}\text { Neonatal } \\
\text { cord blood }\end{array}$ & $1 \mathrm{wk}$ & $6 \mathrm{wk}$ & $3 \mathrm{mo}$ & $6 \mathrm{mo}$ & $1 \mathrm{y}$ & Adults \\
\hline $\mathrm{CD} 16^{+} / 56^{+} / \mathrm{CD}^{-} \mathrm{NK}$ cells & $24(9-33)^{*}$ & $9(5-31)$ & $6(3-9)$ & $6(3-18)$ & $5(3-19)$ & $6(3-11)$ & $14(4-18)$ \\
\hline \multicolumn{8}{|l|}{ NK cell subpopulation } \\
\hline $\mathrm{CD}^{+}$ & $79(38-93) \dagger$ & $91(46-99)$ & $94(82-97)$ & $93(85-98)$ & $91(84-99)$ & 93 (87-99) & $93(85-97)$ \\
\hline $\mathrm{CD}_{45 \mathrm{RA}^{+}}^{+}$ & $79(40-92)$ & $91(50-100)$ & $94(86-99)$ & $95(92-99)$ & $95(83-99)$ & $95(87-99)$ & $96(93-98)$ \\
\hline $\mathrm{CD}_{3} 8^{+}$ & $78(38-90)$ & $91(65-98)$ & $93(84-98)$ & $95(86-99)$ & $95(81-99)$ & 95 (87-99) & $92(79-96)$ \\
\hline $\mathrm{CD}_{45 \mathrm{RO}^{+}}$ & $0(0-3)$ & $1(1-5)$ & $6(1-12)$ & $4(2-7)$ & $7(3-14)$ & $5(2-12)$ & $2(0-17)$ \\
\hline $\mathrm{CD}^{+}$ & $37(19-63)$ & $36(18-67)$ & $36(16-72)$ & $36(6-52)$ & $26(4-58)$ & $19(5-62)$ & $29(11-44)$ \\
\hline $\mathrm{CD} 57^{+}$ & $0(0-2)$ & $0(0-3)$ & $0(0-5)$ & $0(0-24)$ & $12(0-31)$ & $20(9-38)$ & $47(20-58)$ \\
\hline $\mathrm{CD} 25^{+}$ & $1(0-3)$ & $2(1-8)$ & $3(2-7)$ & $4(1-6)$ & $4(0-6)$ & $1(1-7)$ & $5(2-10)$ \\
\hline $\mathrm{HLA}_{-}-\mathrm{DR}^{+}$ & $2(1-18)$ & $6(1-18)$ & $14(4-40)$ & $12(2-22)$ & $10(2-22)$ & $8(3-17)$ & $10(4-21)$ \\
\hline
\end{tabular}

* Median relative frequency followed by minimal and maximal relative frequency between parentheses within the lymphocyte population.

$\dagger \%$ positivity within the $\mathrm{CD} 16^{+} / 56^{+} / \mathrm{CD}^{-} \mathrm{NK}$ cell subpopulation followed by minimal and maximal values between parentheses.

NEONATAL CORD BLOOD
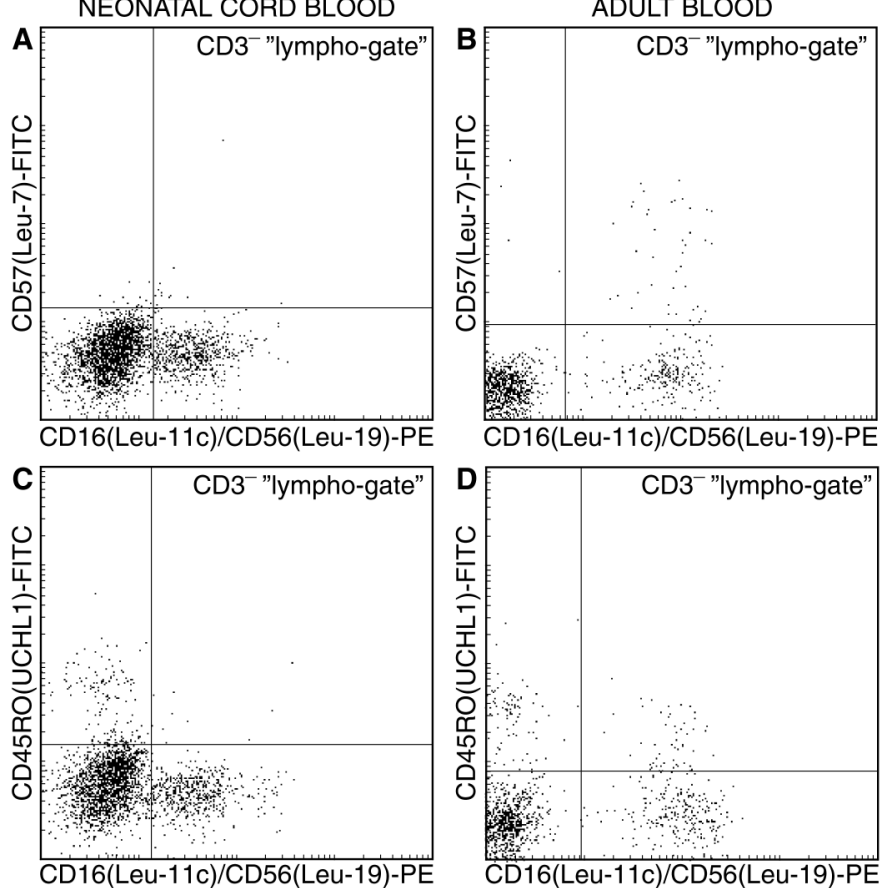

Figure 6. NK cell subpopulations in neonates and adults. Absence of $\mathrm{CD} 57^{+}$ NK cells shortly after birth $(A)$, and a clear subpopulation of $\mathrm{CD} 57^{+} \mathrm{NK}$ cells in adults $(B)$. Hardly any $\mathrm{CD} 45 \mathrm{RO}^{+} \mathrm{NK}$ cells were present in neonates $(C)$, a small subpopulation of $\mathrm{CD} 45 \mathrm{RO}^{+} \mathrm{NK}$ cells was present in adults $(D)$.

lymphocyte counts also increased during the first year of life, albeit this was not statistically significant for $\mathrm{CD}^{-}$B lymphocyte counts. However, the relative frequencies of $\mathrm{CD} 1 \mathrm{c}^{+}$ and $\mathrm{CD}^{+} \mathrm{B}$ lymphocytes were considerably higher throughout the first year of life than in adults. Therefore, CD1c and CD5 could be markers of untriggered B lymphocytes. CD38 is associated with the CD21/CD19 complex on the surface of B lymphocytes and probably has a role as mediator of extracellular signals (34). The relative frequency of $\mathrm{CD}^{2} 8^{+} \mathrm{B}$ lymphocytes was higher in infants than in adults. $\mathrm{CD} 38^{-} \mathrm{B}$ lymphocyte absolute counts were low in infants as well as adults; the high B lymphocyte counts throughout the first year of life were caused by high $\mathrm{CD} 38^{+} \mathrm{B}$ lymphocyte counts. The abundant expression of CD38 on infant's B lymphocytes could be related to a greater metabolic need caused by the many encounters with antigen in primary immune responses, analogous to the situation in T lymphocytes.

The high NK cell counts at birth were for a large part accounted for by $\mathrm{CD}^{+} \mathrm{NK}$ cells. Interestingly, at birth some infants showed large subpopulations of $\mathrm{CD}^{-}, \mathrm{CD} 38^{-}$, and CD45RA ${ }^{-}$NK cells. It could be that these findings are associated with the maturational status of NK cells. However, it is more likely that the high absolute counts of NK cells observed directly after birth are related to a state of NK cell activation during pregnancy, which rapidly disappears during the first weeks after birth; these activated NK cells are postulated to represent a fetal tumor response to maternal antigen, or to play a role in placentation (35). This fits in with the absence of $\mathrm{CD} 57^{+}$NK cells in the first months of life: CD57 is rapidly down-regulated on activation. CD7 is expressed on all resting NK cells and is known to be down-regulated on activation (18). However, we did not find an increase in the number of NK cells positive for other activation markers at birth. CD8 is involved in the recognition of HLA class I molecules, which are expressed by all nucleated cells. It is intriguing that $\mathrm{CD} 8^{+}$ NK cells are present in such large numbers at birth. Perhaps this is related to the maintenance of pregnancy at the immunologic interface between the fetus and its mother. Interestingly, the two infants born at the youngest gestational age (infant 6 at $37 \mathrm{wk}$ and infant 10 at $35 \mathrm{wk}$ ) showed the highest relative frequencies and absolute counts of $\mathrm{CD} 38^{-} \mathrm{NK}$ cells, CD45RA ${ }^{-} \mathrm{NK}$ cells, and $\mathrm{CD}^{-}{ }^{-} \mathrm{NK}$ cells at birth and at $1 \mathrm{wk}$ of age. $\mathrm{CD} 8^{+} \mathrm{NK}$ cell absolute counts were not higher in these two youngest children, however.

In conclusion, we showed that a detailed longitudinal analysis of the absolute counts of lymphocyte subpopulations in infants contributes to the understanding of lymphocyte development after birth. We found that a large pool of naive CD $45 \mathrm{RA}^{+}$-mainly $\mathrm{CD} 4^{+} / \mathrm{CD}^{+}{ }^{+}$- $\mathrm{T}$ lymphocytes continues to be produced during the first year of life, ready to be primed in primary immune responses. With priming, further functional maturation is accompanied by changes in the distribution of lymphocyte subpopulations: adult memory $\mathrm{CD} 45 \mathrm{RO}^{+} \mathrm{T}$ lymphocytes mostly express no CD38 and probably carry more CD45RO molecules on their surface. CD1c, CD5, and CD38 are possible markers of untriggered $\mathrm{B}$ lymphocytes. NK cells 
seem to be more important during pregnancy than thereafter, with absolute numbers falling immediately after birth.

\section{REFERENCES}

1. Comans-Bitter WM, de Groot R, van den Beemd R, Neijens HJ, Hop WCJ, Groeneveld K, Hooijkaas H, van Dongen JJM 1997 Immunophenotyping of blood lymphocytes in childhood. Reference values for lymphocyte subpopulations. J Pediatr 130:388-393

2. Denny T, Yogev R, Gelman R, Skuza C, Oleske J, Chadwick E, Cheng S, Connor E 1992 Lymphocyte subsets in healthy children during the first 5 years of life. JAMA 267:1484-1488

3. Erkeller-Yuksel FM, Deneys V, Yuksel B, Hannet I, Hulstaert F, Hamilton C, Mackinnon H, Turner Stokes L, Munhyeshuli V, Vanlangendonck F, deBruyère $\mathrm{M}$, Bach BA, Lydyard PM 1991 Age-related changes in human blood lymphocyte subpopulations. J Pediatr 120:216-222

4. Heldrup J, Kalm O, Prellner K 1992 Blood T and B lymphocyte subpopulations in healthy infants and children. Acta Paediatr 81:125-132

5. Kotylo PK, Fineberg NS, Freeman KS, Redmond NL, Charland C 1993 Reference ranges for lymphocyte subsets in pediatric patients. Am J Clin Pathol 100:111-115

6. Oski F 1993 The erythrocyte and its disorders. In: Nathan D, Oski F (eds) Hematology of Infancy and Childhood. WB Saunders, Philadelphia, pp 18-43

7. Remy N, Oberreit M, Thoenes G, Wahn U 1991 Lymphocyte subsets in whole blood and isolated mononuclear leukocytes of healthy infants and children. Eur J Pediatr 150:230-233

8. Kutvirt SG, Lewis SL, Simon TL 1993 Lymphocyte phenotypes in infants are altered by separation of blood on density gradients. Br J Biomed Sci 50:321-328

9. de Vries E, de Groot R, de Bruin-Versteeg S, Comans-Bitter WM, van Dongen JJM 1999 Analyzing the developing lymphocyte system of neonates and infants. Eur J Pediatr 158:611-617

10. de Vries E, de Bruin-Versteeg S, Comans-Bitter WM, de Groot R, Boerma GJM, Lotgering FK, van Dongen JJM 1999 Correction for erythroid cell contamination in microassay for immunophenotyping of neonatal lymphocytes. Arch Dis Child 80:F226-F229

11. Ezine S, Ceredig R 1994 Haemopoiesis and early T-cell differentiation. Immunol Today 15:151-154

12. Res P, Blom B, Hori T, Weijer K, Spits H 1997 Downregulation of CD1 marks acquisition of functional maturation of human thymocytes and defines a control point in late stages of human T cell development. J Exp Med 185:141-151

13. Gratama JW, Vogel EJ, van 't Veer MB, de Gast GC, Bolhuis RLH 1995 Activation of CD57+ lymphocytes in relation to cytomegalovirus infection in healthy carriers, allogeneic bone marrow transplant recipients, and B cell chronic lymphocytic leukaemia. In: Schlossman SF, Boumsell L, Gilks W, Harlan JM, Kishimoto T, Morimoto C, Ritz J, Shaw S, Silverstein R, Springer T, Tedder TF, Todd RF (eds) Leukocyte Typing V. White Cell Differentiation Antigens. Oxford University Press, Oxford, pp 422-424

14. Burrows PD, Cooper MD 1997 B cell development and differentiation. Curr Opin Immunol 9:239-244

15. Tsudo M, Uchiyama T, Uchino H 1984 Expression of Tac antigen on activated normal human B cells. J Exp Med 160:612-617

16. Durandy A, Thuillier L, Forveille M, Fischer A 1990 Phenotypic and functional characteristics of human newborns' B lymphocytes. J Immunol 144:60-65

17. Robertson MJ, Cochran KJ, Ritz J 1995 Characterization of surface antigens expressed by normal and neoplastic human NK cells. In: Schlossman SF, Boumsell L, Gilks W, Harlan JM, Kishimoto T, Morimoto C, Ritz J, Shaw S, Silverstein R,
Springer T, Tedder TF, Todd RF (eds) Leukocyte Typing V. White Cell Differentiation Antigens. Oxford University Press, Oxford, pp 1374-1377

18. Rabinowich H, Pricop L, Herberman RB, Whiteside TL 1994 Expression and function of CD7 molecule on human natural killer cells. J Immunol 152:517-526

19. de Vries E, de Bruin-Versteeg S, Comans-Bitter WM, de Groot R, Boerma GJM, Lotgering FK, van Dongen JJM 1998 Longitudinal follow up of blood lymphocyte subpopulations from birth to one year of age. J Pediatr 133:586-588

20. Vanhecke D, Leclercq G, Plum J, Vandekerckhove B 1995 Characterization of distinct stages during the differentiation of human $\mathrm{CD} 69^{+} \mathrm{CD} 3^{+}$thymocytes and identification of thymic emigrants. J Immunol 155:1862-1872

21. Gerli R, Rambotti P, Cernetti C, Velardi A, Spinozzi F 1983 Evidence for phenotypic $\mathrm{T}$ precursor cells in human cord blood. Br J Haematol 53:685-686

22. Foa R, Giubellino MC, Fierro MT, Lusso P, Ferrando ML 1984 Immature T lymphocytes in human cord blood identified by monoclonal antibodies: a model for the study of the differentiation pathway of $\mathrm{T}$ cells in humans. Cell Immunol 89:194-201

23. Griffiths-Chu S, Patterson JAK, Berger CL, Edelson RL, Chu AC 1984 Characterization of immature T cell subpopulations in neonatal blood. Blood 64:296-300

24. Solinger AM 1985 Immature T lymphocytes in human neonatal blood. Cell Immunol 92:115-122

25. Vitiello A, Maccario R, Montagna D, Porta FA, Alberini CM, Mingrat G, AstaldiRicotti GCB, Nespoli L, Ugazio AG 1984 Lymphocyte subpopulations in the neonate: a subset of $\mathrm{HNK} 1^{-}, \mathrm{OKT}^{-}, \mathrm{OKT}^{+}$lymphocytes displays natural killer activity. Cell Immunol 85:252-257

26. DeWaele M, Foulon W, Renmans W, Segers E, Smet L, Jochmans K, van Camp B 1988 Hematologic values and lymphocyte subsets in fetal blood. Am. J. Clin. Pathol. 89:742-746

27. Beck R, Lam-Po-Tang PRL 1994 Comparison of cord blood and adult blood lymphocyte normal ranges: a possible explanation for decreased severity of graft versus host disease after cord blood transplantation. Immunol Cell Biol 72:440-444

28. Malavasi F, Funaro A, Roggero S, Horenstein A, Calosso L, Mehta K 1994 Human CD38: a glycoprotein in search of a function. Immunol Today 15:95-97

29. Brugnoni D, Airo P, Graf D, Marconi M, Lebowitz M, Plebani A, Giliani S, Malacarne F, Cattaneo R, Ugazio AG, Albertini A, Kroczek RA, Notarangelo LD 1994 Ineffective expression of CD40 ligand on cord blood T cells may contribute to poor immunoglobulin production in the newborn. Eur J Immunol 24:1919-1924

30. Fuleihan R, Ahern D, Geha RS 1994 Decreased expression of the ligand for CD40 in newborn lymphocytes. Eur J Immunol 24:1925-1928

31. Kupper H, Seifert M, Fiebig H 1987 Characterization of CD45 antibodies and other studies on the use of workshop antibodies for identifying different leukocytes in tissue specimens. In: McMichael AJ, Beverly PCL, Cobbold S, Crumpton MJ, Gilks W, Gotch FM, Hogg N, Horbon M, Ling N, MacLennan ICM, Mason DY, Milstein C, Spiegelhalter D, Waldmann H (eds), Leukocyte Typing III. White Cell Differentiation Antigens. Oxford University Press, Oxford, p 409

32. Smith SH, Brown MH, Rowe D, Callard RE, Beverley PCL 1986 Functional subsets of human helper-inducer cells defined by a new monoclonal antibody, UCHL1. Immunology 58:63-70

33. Herzenberg LA, Kantor AB, Herzenberg LA 1991 Layered evolution in the immune system: a model for the ontogeny and development of multiple lymphocyte lineages. Ann N Y Acad Sci 651:1-9

34. Funaro A, De Monte LB, Dianzani U, Forni M, Malavasi F 1993 Human CD38 is associated to distinct molecules which mediate transmembrane signaling in different lineages. Eur J Immunol 23:2407-2411

35. Thilaganathan B, Abbas A, Nicolaides KH 1993 Fetal blood natural killer cells in human pregnancy. Fetal Diagn Ther 8:149-153 